\title{
CERAMIC ON METAL SUBSTRATES PRODUCED BY PLASMA SPRAYING FOR THICK FILM TECHNOLOGY
}

\author{
LESZEK GOLONKA \\ Institute of Electron Technology, Technical University of Wroclaw \\ and \\ LECH PAWLOWSKI \\ Institute of Inorganic Chemistry and Metallurgy of Rare Elements, Technical University of Wroclaw, \\ W. Wyspianskiego 27, 50-370 Wroclaw, Poland
}

(Received October 3, 1981; in final form October 28, 1981)

\begin{abstract}
The arc plasma spraying process was applied to obtain ceramic coatings on stainless steel substrates. The outer coatings were formed from pure alumina or alumina $+2 \mathrm{wt} \%$ titania mixture. The nichrome intermediate coating was applied to increase adhesion of ceramic coating to stainless steel. The X-ray analysis, metallographic and SEM investigations of the sprayed coatings were also carried out. The effect of interaction of thick film conductor and resistor compositions was studied. Conductor ink P $202 \mathrm{PdAg}$ and resistor ink DP 1321 were evaluated. The TCR, resistance stability were measured as a function of firing cycles. These parameters and the resistivity of sprayed alumina were compared with standard $96 \%$ alumina substrate characteristics.
\end{abstract}

\section{INTRODUCTION}

The plasma spraying of dielectric coatings onto metallic plates offers the possibility of realization of the substrate for thick film technology. The dielectric coating is the insulator between the metal plate and the thick film circuit and could be also used as the capacitor element. Prepared in this manner substrates have some advantages in comparison with the standard alumina substrates. Smyth et. al. ${ }^{1}$ showed that in the production of 50,000 substrates the cost of a typical alumina substrate $96 \% \mathrm{Al}_{2} \mathrm{O}_{3}$, size $25 \times 25 \times$ $0.65 \mathrm{~mm}$ is in the range of US $\$ 0.08$ for each substrate. The preliminary cost of producing $25 \times 25 \mathrm{~mm}$ sprayed alumina on kovar substrates could be estimated as US \$0.02. The production rate of plasma sprayed substrates reaching several meteres an hour is another important advantage.

The heat conductivity of such substrates can be expressed as:

$$
\lambda_{\mathrm{s}}=\lambda_{1} \frac{l+\mathrm{d}}{\mathrm{d} \frac{\lambda_{1}}{\lambda_{2}}+l}
$$

where: $\lambda$ - heat conductivity, $l$ - dielectric coatings thickness, $\mathrm{d}$-metal plate thickness, s, 1, 2- parameters attributed to substrate, dielectric coating, metal plate.

It is obvious from eq. (1) that the application of a thick plate of good heat conducting metal will result in a good heat conducting substrate. Mackay and Muller $^{2}$ have determined the sprayed alumina heat conductivity $18-28 \mathrm{~W} /(\mathrm{m} \mathrm{K})$ as dependent upon the temperature. Taking from their paper $\lambda_{1} \sim 20 \mathrm{~W} /(\mathrm{m} \mathrm{K})$ and assuming $l=0.1 \mathrm{~mm}$, $\mathrm{d}=0.5 \mathrm{~mm}$ and $\lambda_{2} \sim 400 \mathrm{~W} /(\mathrm{m} \mathrm{K})$ - as for copper - one can estimate the $\lambda_{\mathrm{s}}$ value as nearly $100 \mathrm{~W} /(\mathrm{m} \mathrm{K})$. The value is similar to the heat conductivity of very expensive beryllia ceramics. 
The sprayed coatings surface flatness is also better than for conventional sintered alumina substrates. This parameter is important from the screen printing point of view.

Up to now a similar subject was taken up by, apart from the both mentioned above papers, Braguier et. al. ${ }^{3}$ This paper described sprayed alumina coating on copper plates as a dielectric in micro-strips lines. The idea of sprayed ceramic on metal substrates was shown also in a patent. ${ }^{4}$

For over four years porcelain enamelled substrates have been developed for hybrid circuits applications. A lot of papers on this subject have been published at ISHM conferences from 1978. These kind of substrates can be produced following Stein et. al. ${ }^{5}$ by:

- dipping, slushing or spraying of a water-based slurry or slip,

- electrophoretic deposition of glass,

- electrostatic spraying of dry powder.

However, these technologies have limits for some application e.g. the firing temperature of the substrate is limited to $700^{\circ} \mathrm{C}$. Only Kuzel ${ }^{6}$ has shown the possibility of heating the substrates up to $860^{\circ} \mathrm{C}$. Also the heat conductivity of typical enamels is several times lower than that of alumina (Lebailly ${ }^{7}$ had reported the value of $5.15 \mathrm{~W} /(\mathrm{m} \mathrm{K})$ ). Finally one can refer to "brown plague" - the term which describes the shortages between conductor and steel core reported as often appearing in enamelled substrates, by e.g. Allington and Cote $^{8}$ or Schabecker. ${ }^{9}$

Plasma spraying technology offers an opportunity to avoid the above mentioned problems and to be tried for hybrid microelectronic substrate production.

\section{MATERIALS}

The powders applied in the investigations are characterized in Table I.

TABLE I

Some characteristics of the powders used

\begin{tabular}{|c|c|c|c|c|}
\hline Notations & Powder & X-ray phases & Manufacturer & Remarks \\
\hline 01 & $\mathrm{Al}_{2} \mathrm{O}_{3}+2 \mathrm{wt} . \% \mathrm{TiO}_{2}$ & $\alpha-\mathrm{Al}_{2} \mathrm{O}_{3}$ & $\begin{array}{l}\text { Metco, Inc., } \\
\text { Westbury, USA }\end{array}$ & type $101 \mathrm{SF}$ \\
\hline OD & $\mathrm{Al}_{2} \mathrm{O}_{3}$ & $\alpha-\mathrm{Al}_{2} \mathrm{O}_{3}$ & $\begin{array}{l}\text { Institute of } \\
\text { Nuclear Research, } \\
\text { Warsaw, Poland }\end{array}$ & $\begin{array}{l}\text { produced by } \\
\text { sol-gel } \\
\text { method }\end{array}$ \\
\hline $\mathrm{NC}$ & $\mathrm{NiCr}(80 / 20)$ & & $\begin{array}{l}\text { Technical Univer- } \\
\text { sity of Wroclaw, } \\
\text { Poland }\end{array}$ & $\begin{array}{l}\text { produced by } \\
\text { liquid metal } \\
\text { atomization }\end{array}$ \\
\hline
\end{tabular}

Powder OD is spherical in shape (Figure 1b). This shape provides facilities for feeding the powder to the plasma gun. The powder 01 is shown in Figure 1a.

The distributions of used powder diameters, determined by the sedimentation method, are shown in Figure 2.

Stainless steel, type $1 \mathrm{H} 18 \mathrm{~N} 9 \mathrm{~T}$, was used as the metal plates. The steel was cut into $20 \times 30 \times 2 \mathrm{~mm}$ plates. 

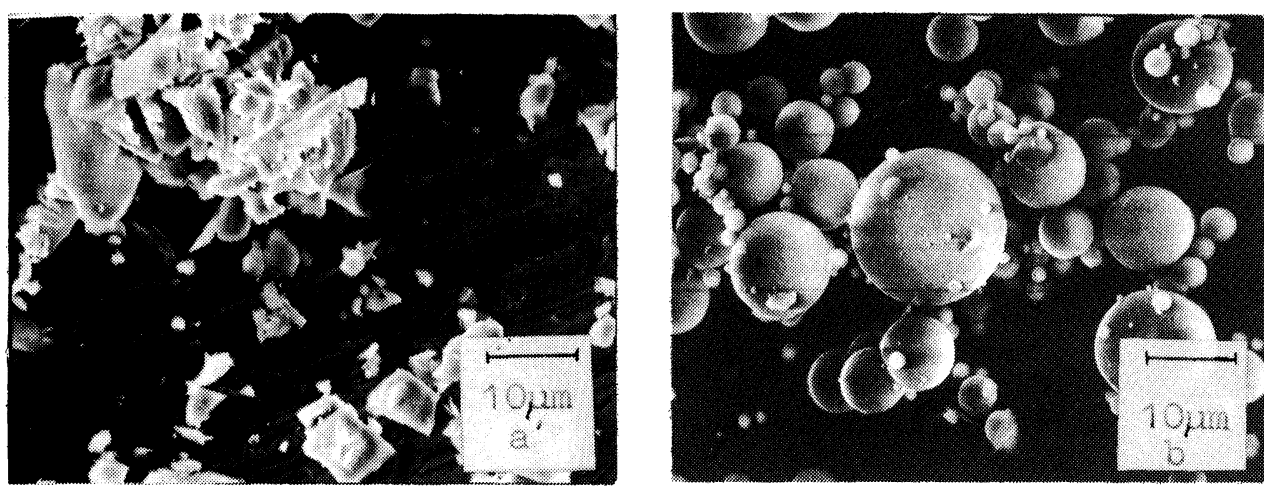

FIGURE 1 The shape of alumina powders used, $a-01, b-O D$.

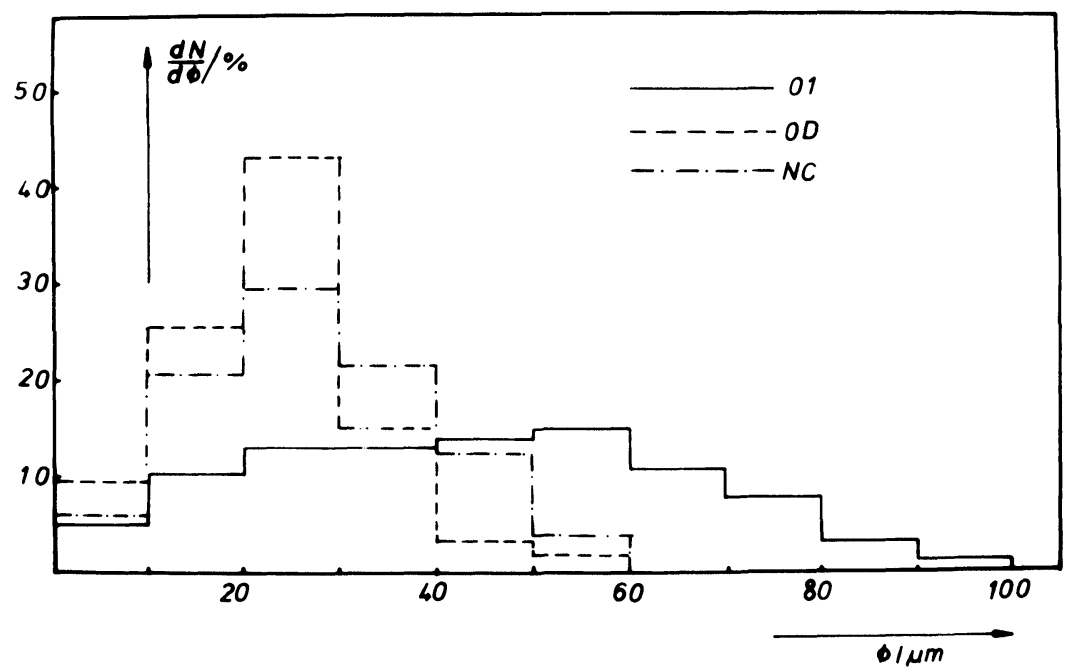

FIGURE 2 The distributions of the used powder diameters.

\section{TECHNOLOGY OF THE SUBSTRATE PRODUCTION}

The steel plates were grit blasted prior to the spraying process. Silica sand with sizes lower than $0.4 \mathrm{~mm}$ was used for blasting. The pressure of air, in this process, was equal to $0.6 \mathrm{MPa}$. The sprayed plates were fixed to the suction cup (Figure 3 ). This solution was chosen to minimize the residual stresses which could appear in the coating after spraying.

The suction cup was mounted in a swivel. The plasma spraying was conducted using a PN-200 plasma installation. The operational parameters are shown in Table II.

During the spraying process air cooling was used. The $\mathrm{NiCr}(80 / 20)$ subcoat was first deposited and then the alumina coating was applied. 


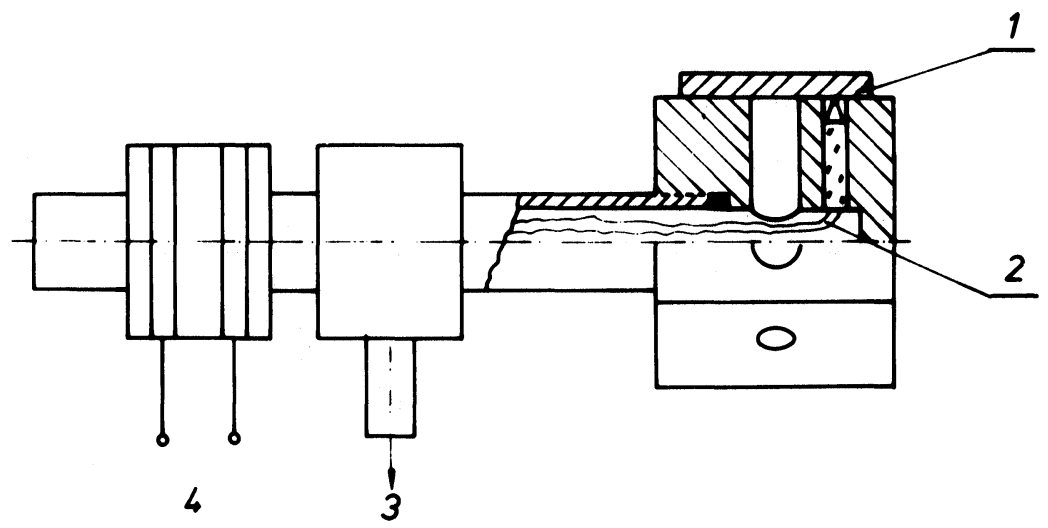

FIGURE 3 Suction cup scheme, 1 - metal plate for spraying, 2 - Ni - NiCr thermocouple, 3 - vacuum pump, 4 - temperature monitor.

TABLE II

Plasma spray parameters

\begin{tabular}{|c|c|c|c|c|}
\hline Powder & & 01 & OD & $\mathrm{NC}$ \\
\hline $\begin{array}{l}\text { Plasma gases:- } \\
\text { Primary: Argon } \\
\text { Secondary: Hydrogen } \\
\text { Feeding gas:- } \\
\text { Argon } \\
\text { Current } \\
\text { Voltage } \\
\text { spraying distance } \\
\text { sliding velocity } \\
\text { no. sliding cycles } \\
\text { substrate } \\
\text { front temperature }{ }^{a}:- \\
\text { prior to spraying } \\
\text { after spraying }\end{array}$ & $\begin{array}{l}\left(\mathrm{Ndm}^{3} / \mathrm{s}\right) \\
\left(\mathrm{Ndm}^{3} / \mathrm{s}\right) \\
\left(\mathrm{Ndm}^{3} / \mathrm{s}\right) \\
(\mathrm{A}) \\
(\mathrm{V}) \\
(\mathrm{cm}) \\
(\mathrm{cm} / \mathrm{s})\end{array}$ & $\begin{array}{c}0.083 \\
600 \\
65 \\
10 \\
0.4 \\
1\end{array}$ & $\begin{array}{l}0.083 \\
600 \\
65 \\
10 \\
0.4 \\
2\end{array}$ & $\begin{array}{c}0.083 \\
500 \\
65 \\
10 \\
0.4 \\
1\end{array}$ \\
\hline
\end{tabular}

$\dagger_{\text {averaged values }}$

\section{RESULTS}

The introductory researches were aimed at finding an alumina powder which when sprayed on to a nichrome substrate maintains adhesion up to a temperature of $800^{\circ} \mathrm{C}$. In these researches the $\mathrm{Al}_{2} \mathrm{O}_{3}$ powder, Metco - type $105 \mathrm{SF}$, was eliminated.

\subsection{Physical and Structural Properties of the Alumina Coatings.}

The X-ray investigations were carried out using $\mathrm{Cu} \mathrm{K} \alpha$ radiation. The bias cross-section of sprayed samples were examined using metallographical and Vickers microhardness tests. The tensile bond strength of the sprayed coatings was determined according to the norm. ${ }^{10}$ The results of these investigations are shown in Table III. 
TABLE III

Some physical properties of plasma sprayed alumina coatings

\begin{tabular}{llllll}
\hline Coating & $\begin{array}{l}\text { Strongest } \\
\text { peaks in- } \\
\text { tensity } \\
\text { ratio } \\
\mathrm{I}_{\delta} / \mathrm{I}_{\alpha}\end{array}$ & Density & $\begin{array}{c}\text { Vickers micro- } \\
\text { hardness } \\
\text { phases }\end{array}$ & $\begin{array}{c}\text { Tensile } \\
\text { bond strength }\end{array}$ \\
\hline OD & $\begin{array}{l}\alpha-\mathrm{Al}_{2} \mathrm{O}_{3} \\
\delta-\mathrm{Al}_{2} \mathrm{O}_{3} \\
\alpha-\mathrm{Al}_{2} \mathrm{O}_{3} \\
01\end{array}$ & 1.6 & 3450 & 12300 & $(\mathrm{MPa})$ \\
\hline
\end{tabular}

\footnotetext{
${ }^{\mathrm{a}}$ The phases were identified using ASTM cards no. 10-174 $\left(\alpha-\mathrm{Al}_{2} \mathrm{O}_{3}\right)$ and 16-394 $\left(\delta-\mathrm{Al}_{2} \mathrm{O}_{3}\right)$.

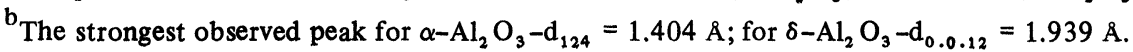

${ }^{c}$ Failure occurred at the intermediate coating/alumina interface.
}

The sprayed alumina contains the metastable phase $\delta-\mathrm{Al}_{2} \mathrm{O}_{3}$ which considerably lowers the coating density $\left(\rho \sim 4000 \mathrm{~kg} / \mathrm{m}^{3}\right)$ for corundum. The microhardness, determined under the load $2 \mathrm{~N}$, is also lower than for sintered carborundum (HV $20000 \mathrm{MPa}$ ). The coatings sprayed using OD powder have higher corundum content. Therefore they conduct the heat better. The sprayed alumina coatings surface (Figure 4) shows that the sprayed powder grains were molten during impact with the substrate. They had melted on to the surface. The small grains, appearing after large grains had formed on the substrate, are also visible.

There were no visible fractures on the coatings surface. The coating sprayed using 01 powder has a smoother surface than that of OD. The roughness of the first, determined using a ZEISS-ME 10 apparatus, is equal to $3.1 \mu \mathrm{m} \mathrm{AA}$.

The metallographical cross-section shown in Figure 5 exhibits some pores and discontinuities in the coating.
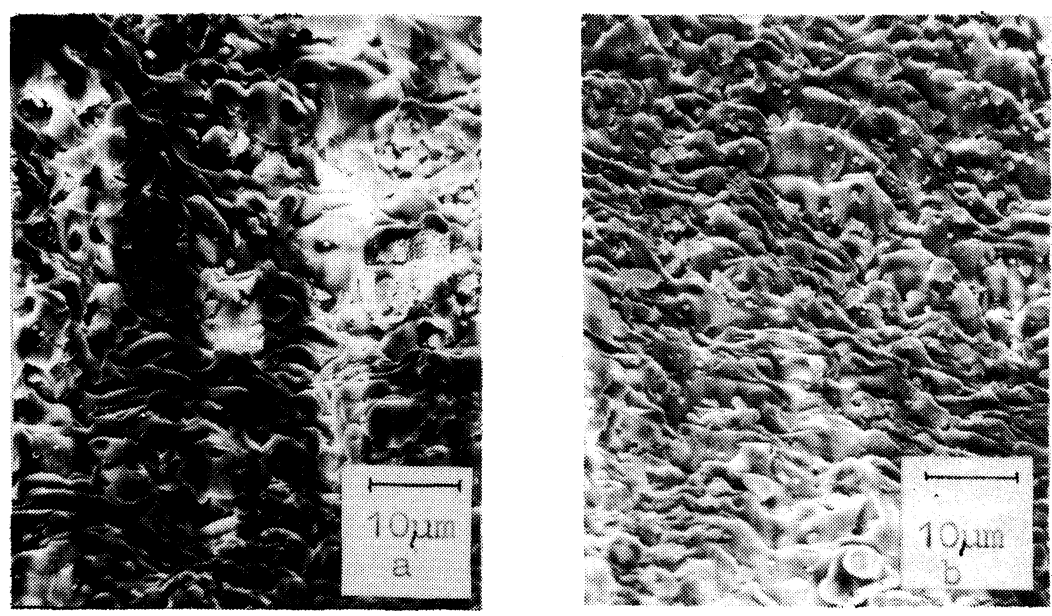

FIGURE 4 Sprayed alumina coatings surface, $a-O D, b-01$. 


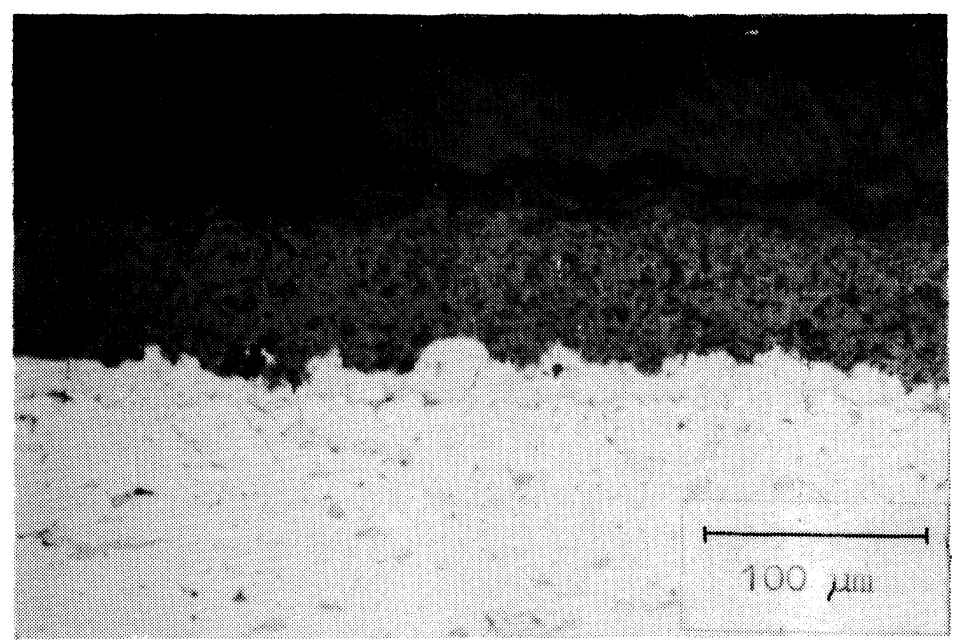

FIGURE 5 Sprayed coating cross-section, powder type 01.

\subsection{Electrical Properties of the Alumina Coatings.}

Two different types of ceramic coatings using OD and 01 alumina powders have been tested. Dielectric properties of the ceramic layers were tested in a capacitor system (Electrode area, $S=1 \mathrm{~cm}^{2}$ ), with stainless steel and thick film electrodes. A thick film, P 202 $(\mathrm{PdAg})$, electrode was fired at $800^{\circ} \mathrm{C}$ peak temperature for 10 minutes. Surface resistivity was determined for a resistor $105 \mathrm{~mm}$ length and $0.5 \mathrm{~mm}$ width. The test pattern used is shown in Figure 6. Electrical parameters of the ceramic layers examined are summarized in Table IV. The insulation properties of sprayed OD powder coatings were much better than that of 01 powder. Electrical parameter differences were in 2 or 3 orders of magnitude in favour of the OD powder coatings.

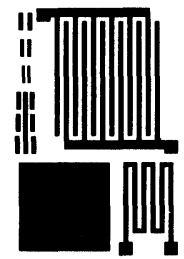

FIGURE 6 Test pattern.

TABLE IV

Electrical properties of plasma sprayed alumina coatings

\begin{tabular}{lcc}
\hline & OD coating & 01 coating \\
\hline Volume resistivity $(\Omega \mathrm{cm})$ & $\sim 10^{9}$ & $\sim 10^{7}$ \\
Surface resistivity $(\Omega / \mathrm{sq})$. & $\sim 10^{12}$ & $\sim 10^{9}$ \\
Dissipation factor $(1.5 \mathrm{kHz})_{\text {Capacity }^{\mathrm{a}}(\mathrm{pF}) \quad(1.5 \mathrm{kHz})}^{0.015}$ & 3.5 \\
\hline
\end{tabular}

${ }^{a}$ Capacity measured between the metal plate and the thick film electrode, $\mathrm{S}=1 \mathrm{~cm}^{2}$, coatings thickness: $\mathrm{OD} \sim 50 \mu \mathrm{m}, 01 \sim 20 \mu \mathrm{m}$. 


\subsection{Electrical Properties of the Thick Film Resistors.}

The properties of a thick film resistor system made on the tested substrates was determined. The conductor ink, P 202 (PdAg), and the resistor ink, Du Pont DP 1321, were evaluated. The resistors and conductors were fired separately. All firings were carried out

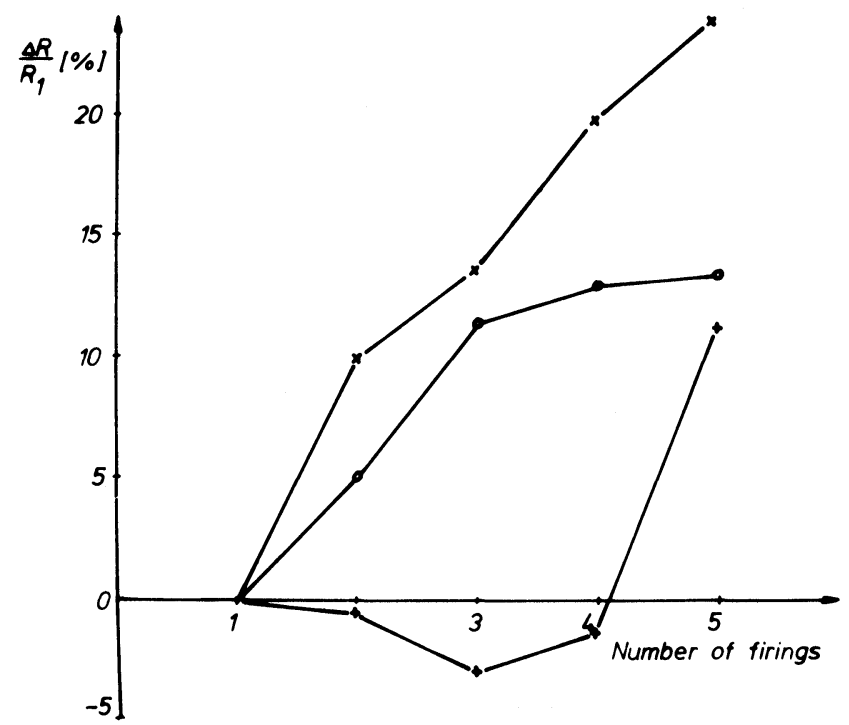

FIGURE 7 Multiple firing behaviour of sprayed coatings: OD powder "x", 01 powder "“"; $96 \%$ alumina substrate "o".

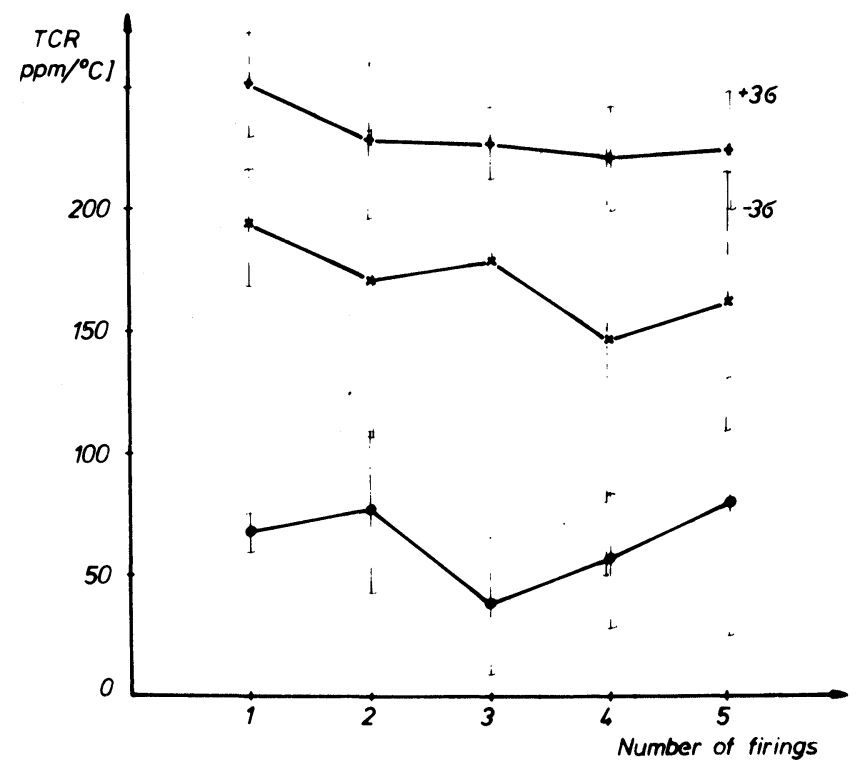

FIGURE 8 Multiple firing behaviour of sprayed coatings: OD powder " $x$ ", 01 powder “+”; $96 \%$ alumina substrate "o". 
at $800^{\circ} \mathrm{C}$ peak temperature for 10 minutes on a profile used for DP 1321 ink on alumina substrates. The tested resistors were $5 \times 5 \mathrm{~mm}$ in dimension.

The measured sheet resistivities and hot TCR were in agreement with the manufacturer's data for DP 1321 on the alumina substrates. The sheet resistivities, $70 \Omega / \mathrm{sq}$. and $75 \Omega /$ sq., were obtained for OD and 01 powder coatings respectively. Hot TCR, 250 $\mathrm{ppm} /{ }^{\circ} \mathrm{C}$ and $190 \mathrm{ppm} /{ }^{\circ} \mathrm{C}$, were determined. The effect of refiring on the resistance and TCR is shown in Figures 7 and 8. For comparison the behaviour of the same resistors on 96\% alumina substrates are also shown. The resistors made on OD powder coating substrates had better refiring stability than the resistors on 01 powder coating substrates. The stabilities of the resistors on $96 \%$ alumina substrates and OD powder coatings were similar. TCR changes during refiring were comparable for all types of substrates.

\section{CONCLUSION}

The resistors printed on stainless steel $\mathrm{NiCr} / \mathrm{Al}_{2} \mathrm{O}_{3} /(\mathrm{OD})$ substrates show sufficient resistance stability and sheet resistivity comparable to those printed on conventional alumina substrates and a TCR that is only slightly higher. The sheet resistivity and dissipation factor of sprayed ceramics type OD are better than sprayed 01 ceramics but significantly worse than sintered alumina substrates. Therefore, the technology presented permits substrates to be obtained with electrical parameters comparable to conventional sintered alumina ceramics.

\section{ACKNOWLEDGEMENTS}

The authors are grateful to Prof. B. Licznerski for the inspiration to do this work and to Prof. A. Czernichowski for many discussions.

\section{REFERENCES}

1. R.T. Smyth, F.J. Dittrich, J.D. Weir, "Thermal spraying - a new approach to thick film circuit manufacture", Proc. Conf. Advances in Surface coating Technology, London 1978/The Welding Institute, London p. 223 (1979).

2. T.L. Mackay, A.N. Muller, "Plasma spraying dielectric coating for heat sinks in electronic packaging", Ceramic Bulletin, 46, p. 833 (1967).

3. M. Braguier, J. Bejat, R. Tueta, M. Verna, G. Aubin, C. Naturel, "Improvements of plasma spraying process for hybrid microelectronics", Proc. Conf. on Hybrid Microelectronics, Kent 1973/ I.E.R.E. London p. 251 (1973).

4. Polish patent no. 161863, (1973).

5. S.J. Stein, C. Huang, A.S. Gelb, "Comparison of enamelled steel substrate for thick film use", Proc. Conf. on Hybrid Microelectronics, Ghent p. 525 (1979).

6. R. Kuzel, J. Broukal, "Enamelled steel substrates for printed circuits", Proc. Conf. on Hybrid Microelectronics, Avignon p. 365 (1981).

7. M. Lebailly, "Steel enamelled substrates", ibid, p. 362.

8. T.R. Allington, R.E. Cote, "Characterization of thick films compositions on porcelain steel substrates", Solid State Technology, January, 811979.

9. R.B. Schabecker, "Porcelain enamelled substrates for hybrid circuits and printed circuits", Proc. Conf. on Hybrid Microelectronics, Ghent p. 539 (1979).

10. "Adhesion or cohesive strength of flame-sprayed coatings", ASTM norm, pp 633-69. 

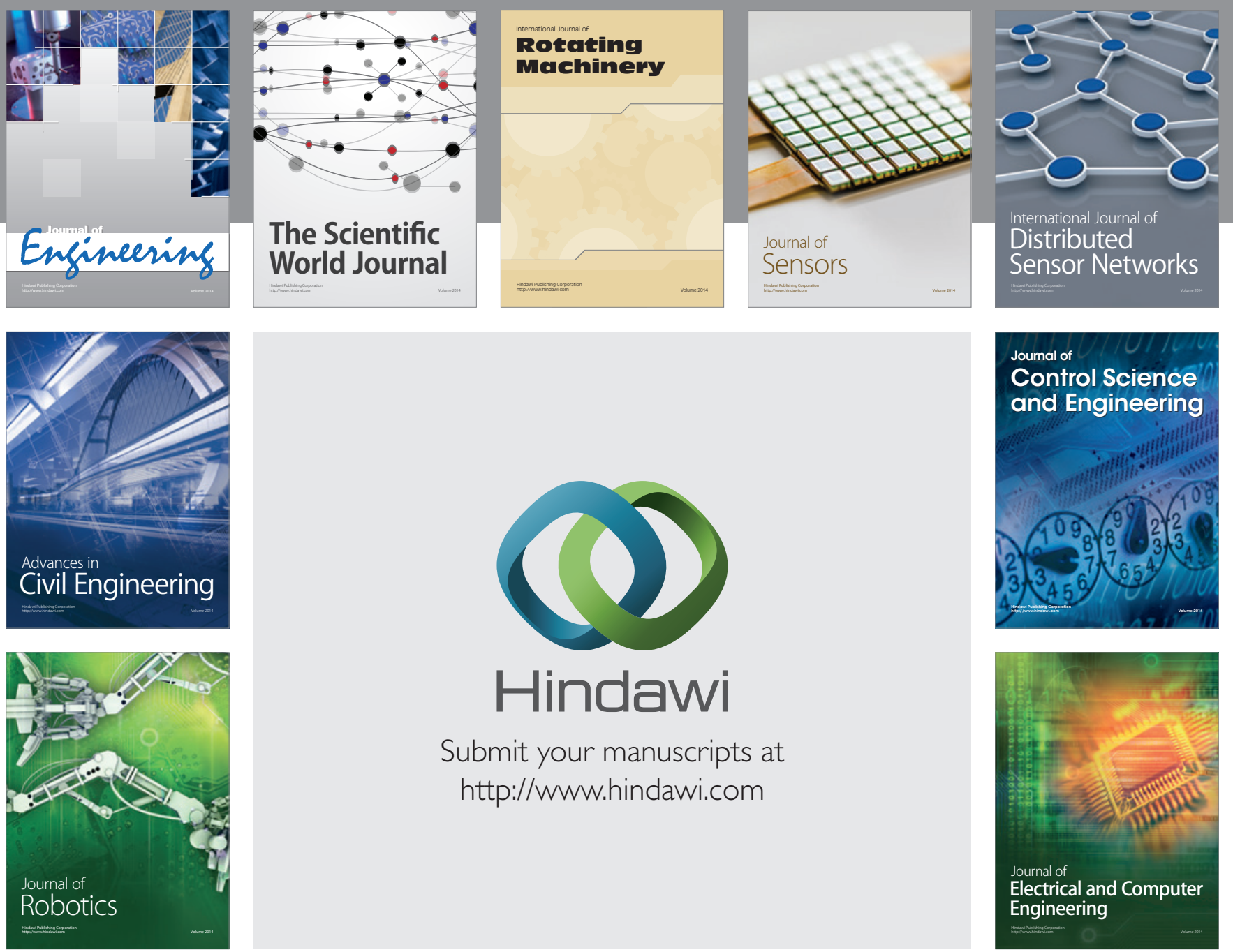

Submit your manuscripts at

http://www.hindawi.com
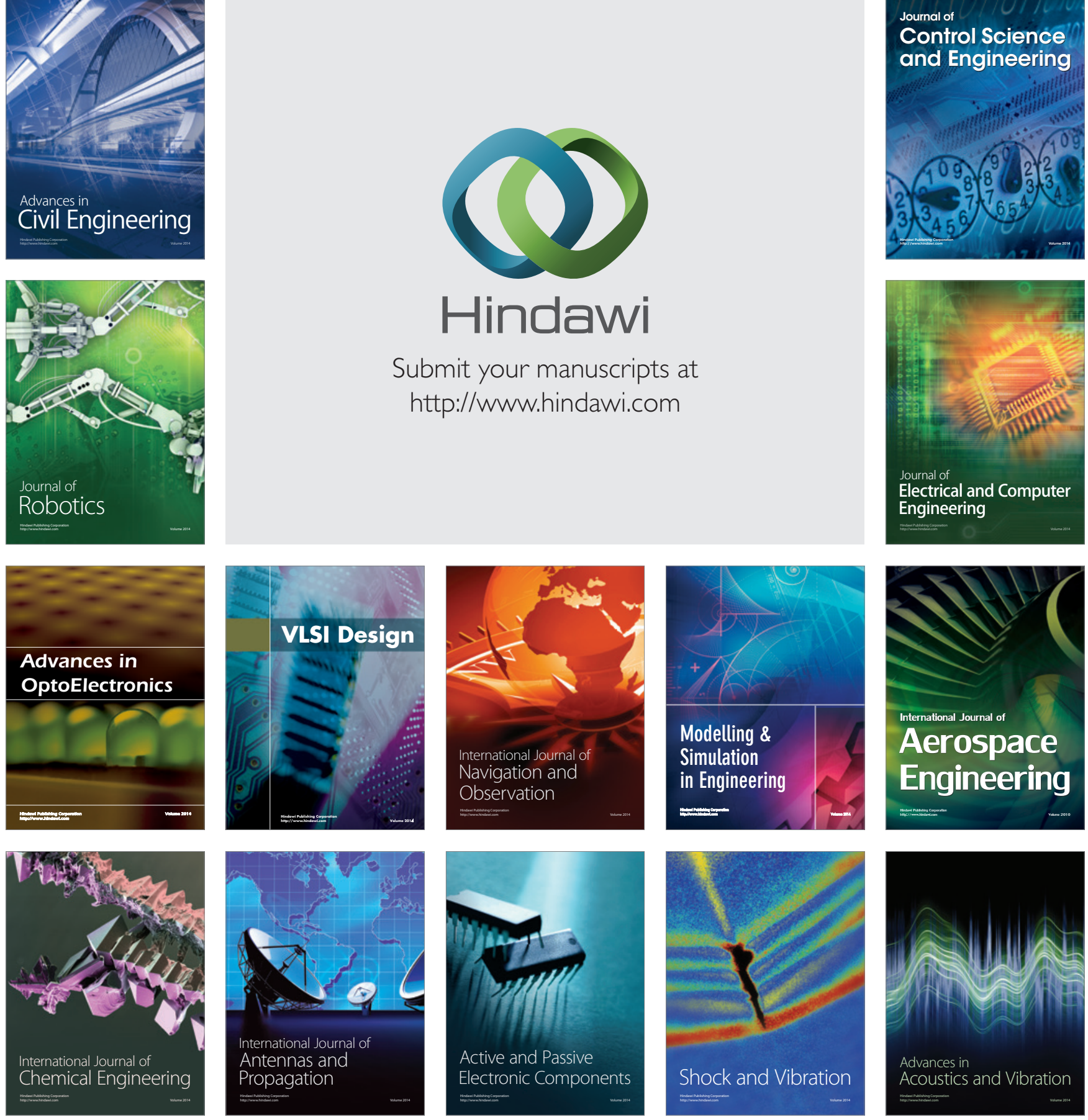